\title{
PENINGKATAN KESADARAN HUKUM MASYARAKAT TERHADAP PERAN MASYARAKAT DALAM PENCEGAHAN DAN PENANGGULANGAN KEKERASAN DALAM RUMAH TANGGA
}

\author{
Tundjung HS ${ }^{1}$, Ida Kurnia ${ }^{2}$, dan Ade Adhari ${ }^{3}$ \\ ${ }^{1}$ Fakultas Hukum, Universitas Tarumanagara \\ Email: tundjunghidayat@yahoo.com \\ ${ }^{2}$ Fakultas Hukum, Universitas Tarumanagara \\ Email: idah@fh.untar.ac.id \\ ${ }^{3}$ Fakultas Hukum, Universitas Tarumanagara \\ Email: adea@fh.untar.ac.id
}

\begin{abstract}
ABSTRAK
Kesadaran hukum merupakan elemen penting guna memastikan hukum dapat bekerja dengan baik di masyarakat. Tingkat kesadaran hukum yang rendah sering menjadi causa hukum tidak ditaati dengan baik oleh masyarakat. Dalam hal pencegahan dan penanggulangan kekerasan dalam rumah tangga (KDRT) penting untuk memastikan masyarakat mengetahui aturan hukum dan substansi aturan hukum yang mengatur mengenai KDRT. Salah satu problem mendasar dalam pencegahan dan penanggulangan KDRT adalah masyarakat tidak memahami perannya. Hal tersebut juga yang dihadapi oleh masyarakat di wilayah Kecamatan Grogol Petamburan. Dalam rangka mengatasi masalah tersebut, kegiatan pengabdian kepada masyarakat dilakukan dengan metodeberupa ceramah atau penyuluhan serta diskusi untuk memperjelas pemahaman peserta penyuluhan ini.

Hasil kegiatan penyuluhan dari pengabdian kepada masyarakat tersebut berupa peningkatan kesadaran hukum masyarakat mengenai perannya terhadap KDRT yaitu mencegah berlangsungnya tindak pidana, memberikan perlindungan kepada korban, memberikan pertolongan darurat dan membantu proses pengajuan permohonan penetapan perlindungan.
\end{abstract}

Kata Kunci: Kesadaran Hukum, KDRT, Peran Masyarakat

\section{PENDAHULUAN}

Mengawali tulisan ini penting untuk diketengahkan rumusan normatif Pasal 1 Undang-Undang Nomor 1 Tahun 1974 tentang Perkawinan, perkawinan ialah ikatan lahir batin antara seorang pria dengan seorang wanita sebagai suami istri dengan tujuan membentuk keluarga (rumah tangga) yang bahagia dan kekal berdasarkan Ketuhanan Yang Maha Esa. Formulasi yuridis tersebut menjadi penanda bahwa tujuan perkawinan adalah mencapai kebahagiaan lahir dan batin. Kebahagiaan menjadi tujuan dari pada lembaga perkawinan, hal tersebut menjadi wajar karena pada prinsipnya almost everyone wants a happy life (Babette Pouwels: 2011).Keluarga merupakan bentuk atau cara yang dipilih manusia untuk mendapatkan kebahagiaan.

Dalam realitasnya keluarga (rumah tangga) yang utuh, bahagia, tenteram, damai dan sejahtera di mana terdapat hubungan yang rukun dan harmonis antara suami, isteri, anak-anak, dan anggota keluarga yang lain (ayah, ibu, kakak, adik, keponakan dari kedua belah pihak, dalam hal ini termasuk asisten rumah tangga) yang menjadi idaman setiap orang tersebut sulit untuk diwujudkan. Hal tersebut disebabkan masing-masing anggota keluarga (rumah tangga) memiliki karakter yang berbeda satu sama lain, maupun hal lain (sebagai contoh adalah penghasilan suami dan/atau isteri yang kurang mencukupi, suami mempunyai wanita idaman lain atau sebaliknya isteri yang mempunyai pria idaman lain, anak-anak yang nakal dan sulit diatur, serta suami atau isteri atau anak yang suka mabuk atau terjerat narkoba). Hal tersebut selain dapat mempengaruhi kualitas hubungan orang-orang yang ada di dalam keluarga (rumah tangga) yang bersangkutan, juga dapat menjadi pemicu (trigger) terjadinya kekerasan dalam rumah tangga, baik berupa 
kekerasan fisik (sebagai contoh penganiayaan, perbuatan a susila atau pelecehan seksual), kekerasan psikis maupun kekerasan seksual.

Kekerasan yang terjadi dalam konteks rumah tangga atau yang dikenal dengan domestic violence menjadi permasalahan yang merintangi terwujudnya kebahagiaan dalam rumah tangga. Dalam sebuah tulisan dikatakan domestic and family violence is a significant social problem which has become the focus of increased community concern (Queensland Domestic and Family Violence Research Centre: 2018). Keberadaan kekerasan dalam rumah tangga tersebut tentunya bertentangan dengan hak asasi manusia sebagaimana terejahwantah dalam Undang-Undang Dasar Negara Republik Indonesia Tahun 1945.

Kekerasan Dalam Rumah Tangga (KDRT) merupakan salah satu masalah yang marak terjadi di Indonesia. Sebagai bukti berikut ini adalah data statistik KDRT yang terjadi antara tahun 20142016 di berbagai provinsi di Indonesia:

Tabel 1.

Jumlah KDRT 2014-2016

\begin{tabular}{llrrr}
\hline No & \multicolumn{1}{c}{ Kepolisian Daerah } & $\mathbf{2 0 1 4}$ & $\mathbf{2 0 1 5}$ & $\mathbf{2 0 1 6}$ \\
\hline 1. & Aceh & 352 & 440 & 450 \\
\hline 2. & Sumatera Utara & - & - & - \\
\hline 3. & Sumatera Barat & 371 & 325 & 387 \\
\hline 4. & Riau & 316 & 318 & 366 \\
\hline 5. & Jambi & 243 & 250 & 237 \\
\hline 6. & Sumatera Selatan & 601 & 650 & 576 \\
\hline 7. & Bengkulu & 161 & 129 & 215 \\
\hline 8. & Lampung & 85 & 148 & 241 \\
\hline 9. & Bangka Belitung & 70 & 62 & 46 \\
\hline 10. & Kepulauan Riau & 196 & 200 & 196 \\
\hline 11. & Metro Jaya & 1199 & 1027 & 1324 \\
\hline 12. & Jawa Barat & 570 & 591 & 686 \\
\hline 13. & Jawa Tengah & 486 & 408 & 258 \\
\hline 14. & DI Yogyakarta & 157 & 136 & 158 \\
\hline 15. & Jawa Timur & 251 & 440 & 491 \\
\hline 16. & Banten & 60 & 65 & 70 \\
\hline 17. & Bali & 216 & 223 & 186 \\
\hline 18. & Nusa Tenggara Barat & 309 & 320 & 454 \\
\hline 19. & Nusa Tenggara Timur & 498 & 412 & 456 \\
\hline 20. & Kalimantan Barat & 242 & 220 & 193 \\
\hline 21. & Kalimantan Tengah & 25 & 52 & 52 \\
\hline 22. & Kalimantan Selatan & 87 & 103 & 71 \\
\hline 23. & Kalimantan Timur & 214 & 248 & 341 \\
\hline 24. & Sulawesi Utara & 367 & 254 & 789 \\
\hline 25. & Sulawesi Tengah & 381 & 395 & 540 \\
\hline 26. & Sulawesi Selatan & 645 & 1051 & 1019 \\
\hline 27. & Sulawesi Tenggara & 355 & 138 & 204 \\
\hline 28. & Gorontalo & 205 & 193 & 245 \\
\hline 29. & Maluku & 149 & 135 & 138 \\
\hline & & & & \\
\hline
\end{tabular}




\begin{tabular}{llrrr}
\hline 30. & Maluku Utara & 37 & 33 & 52 \\
\hline 31. & Papua & 538 & 462 & 492 \\
\hline 32. & Papua Barat & - & 55 & - \\
\hline
\end{tabular}

Sumber: Statistik Kriminal 2017 Badan Pusat Statistik

Data pada tabel 1 menunjukkan bahwa angka KDRT di Indonesia secara umum mengalami peningkatan di masing-masing wilayah di Indonesia. Keberadaan Undang-Undang Nomor 23 Tahun 2004 tentang Penghapusan Kekerasan Dalam Rumah Tangga ternyata tidak memberikan jaminan bahwa tidak akan terjadi KDRT. Salah satu faktor penting untuk mengurai permasalahan KDRT adalah dengan meningkatkan kesadaran hukum masyarakat mengenai perannya sebagaimana telah diatur dalam Undang-Undang Nomor 23 Tahun 2004 tentang Penghapusan Kekerasan Dalam Rumah Tangga (UU KDRT). Wilayah yang disasar dalam usaha meningkatkan kesadaran hukum ini adalah masyarakat wilayah Kecamatan Grogol Petamburan. Dalam pelaksanaan pengabdian kepada masyarakat belum menunjukkan adanya penurunan tingkat kekerasan dalam masyarakat. Hal ini menunjukkan perlunya kegiatan pengabdian kepada masyarakat yang harus dilakukan secara terus menerus.

\section{METODE PELAKSANAAN PKM}

Pelaksanaan pengabdiaan kepada masyarakat dilakukan dengan menggunakan metode pelaksanaan yang rangkaian kegiatannya berupa:

1. Survey

Survey merupakan tahapan awal pelaksaan kegiatan pengabdian kepada masyarakat yang dilakukan. Kegiatan survey dilakukan ke Kecamatan Grogol Petamburan. Pada kegiatan ini, pelaksana PKM menemui Camat Grogol Petamburan untuk menggali lebih dalam permasalahan krusial yang terjadi di masyarakat sekitar. Hasil kegiatan ini didapatkan informasi bahwa kekerasan dalam rumah tangga menjadi salah satu permasalahan yang sering terjadi. Masyarakat selama ini belum pernah mendapatkan informasi mengenai Kekerasan Dalam Rumah Tangga.

2. Ceramah atau Penyuluhan

Pada saat kegiatan pengabdian kepada masyarakat, ceramah digunakan untuk menginformasikan perihak kebijakan dan regulasi yang terkait dengan pencegahan dan penanggulangan kekerasan dalam rumah tangga. Metode cermah dilakukan untuk:

a. menyajikan materi aturan hukum kekerasan dalam rumah tangga;

b. menginformasikan atau menjelaskan kebijakan pencegahan dan peanggulangan kekerasan dalam rumah

c. merangsang peserta pengabddian masyarakat agar memiliki keingintahuan terhadap kebijakan pencegahan dan peanggulangan kekerasan dalam rumah

Pemilihan metode ceramah dikarenakan peserta pengabdian kepada masyarakat yang jumlahnya banyak dan para peserta tidak mengetahui aturan yang lengkap mengenai pencegahan dan peanggulangan kekerasan dalam rumah tangga.

Pada sesi ceramah para pelaksana PKM menyampaikan materi antara lain:

a. Pencegahan kekerasan dalam rumah tangga;

b. Penanggulangan kekerasan dalam rumah tangga; dan

c. Peran masyarakat dalam membantu mencegah dan menanggulangu kekerasan dalam rumah tangga.

3. Diskusi

Setelah sesi ceramah atau penyuluhan, disediakan waktu untuk berdiskusi melalui pertanyaan dari peserta dan dijawab oleh penceramah atau penyulih tentang materi. Pada sesi ini peserta pengabdian kepada masyarakat dapat mengajukan pertanyaan-pertanyaan yang kemudian 
dijawab oleh pelaksana PKM. Selain itu, peserta dapat pula memberikan informasi atau pengalaman seputar kekerasan dalam rumah tangga. Sesi ini dibuka sebanyak 3 (tiga) kali dengan masing-masing sesi dapat menerima 5 pertanyaan.

\section{HASIL DAN PEMBAHASAN}

Pembicaraan mengenai kesadaran hukum masyarakat mengenai perannya dalam mencegah dan menanggulangi KDRT sangat terkait dengan sistem hukum. Lawrence M. Friedman dalam bukunya berjudul The Legal System: A Social Science Perspective mengatakan hukum sebagai sebuah sistem mengandung 3 (tiga) komponen yaitu substansi hukum (legal substance), struktur hukum (legal structure), dan budaya hukum (legal culture) (Lawrence M. Friedman:1969). Lawrence M. Friedman memaknai substansi hukum sebagai aturan atau norma, dengan mengatakan bahwa "substance is what we call the actual rules or norms used by institutions, (or as the case may be) the real observable behavior patterns of actors within the system". Wujud konkret substansi hukum adalah dengan adanya UU KDRT atau segala jenis produk hukum berkaitan dengan KDRT yang dihasilkan oleh lembaga yang berwenang. Selanjutnya struktur hukum didefinisikan oleh Friedman sebagai "is the body, the framework, the longlasting shape of the system; the way courts of police depatements are organized, the lines of jurisdication, the table of organization". Berbagai lembaga hukum yang dibentuk oleh Pemerintah yang tugas dan fungsinya berkenaan dengan persoalan KDRT menunjukkan bentuk dari struktur hukum. Terakhir, kultur hukum oleh Friedman diartikan sebagai “... attitude and values that related to law and legal system, together with those attitudes and values affecting behavior related to law and its institutions, either positively or negatively.

Pandangan Friedman memberikan kesadaran pada kita bahwa institusi hukum harus dilihat dalam kacamata sebuah sistem. Suatu sistem hukum bukanlah suatu perangkat yang abstrak dari normanorma tetapi merupakan suatu proses kegiatan atau pekerjaan. Dengan demikian apabila hukum ingin digunakan sebagai sarana dalam mengatasi KDRT, maka peran masing-masing sub-sistem harus dioptimalkan. Tidak bisa hanya mengandalkan salah satu sub-sistem saja, misalnya hanya sub-sistem substansi hukum/regulasi melainkan harus ketiganya.

Kultur hukum merupakan salah satu sub-sistem hukum yang sering kali terabaikan, teranaktirikan bila dibandingkan dengan substansi atau struktur hukum. Kultur hukum secara sederhana berintikan mengenai kesadaran hukum (yaitu kesadaran atau nilai-nilai yang terdapat di dalam diri manusia tentang hukum atau tentang hukum yang diharapkan ada; yang merupakan konsepsikonsepsi abstrak di dalam diri manusia tentang keserasian antara ketertiban dengan ketenteraman yang dikehendaki atau yang sepantasnya), ${ }^{1}$ dan kebiasaan hukum. Kesadaran hukum yang rendah sering kali menjadi akar penyebab hukum tidak mampu berjalan dengan baik dalam usahanya memberikan perlindungan kepada individu dari berbagai perbuatan yang merugikan, termasuk KDRT.

Menurut Kutschinky (Soerjono Soekanto: 1982), indikator-indikator dari masalah kesadaran hukum dapat dilihat dari beberapa hal, antara lain Pengetahuan tentang peraturanperaturan hukum (law awareness); Pengetahuan tentang isi peraturan-peraturan hukum (law acquaintance); Sikap terhadap peraturan-peraturan hukum (legal attitude); dan Pola-pola perikelakuan hukum (legal behaviour). Pandangan Kutschinky di atas menunjukkan bahwa problem kesadaran hukum masyarakat berkenaan dengan KDRT dapat dilihat dari kriteria di atas. Kelurahan Tanjung Duren Utara, Kecamatan Grogol Petamburan Kota Administrasi Jakarta Barat

\footnotetext{
${ }^{1}$ Soerjono Soekanto, "Kesadaran Hukum dan Kepatuhan Hukum", dalam Soerjono Soekanto, Kesadaran Hukum dan Kepatuhan Hukum, Edisi Pertama, (Jakarta: CV Rajawali, 1982), halaman 152 dan 239.
} 
merupakan salah satu wilayah yang warganya belum memahami berbagai peraturan mengenai KDRT, bahkan masih banyak warga yang belum memahami substansi yang diatur dalam UU KDRT. Dengan demikian perlu ada upaya untuk meningkatkan kesadaran hukum masyarakat. Hal ini mengingat secara substansial UU KDRT memiliki ketentuan yang penting untuk diketahui oleh setiap individu yang terdapat dalam lingkup keluarga secara khusus dan masyarakat secara umum. Ketentuan yang dimaksud antara lain: pertama, adanya larangan untuk melakukan KDRT, baik kekerasan yang dilakukan dengan cara kekerasan fisik, kekerasan psikis, kekerasan seksual dan penelantaran rumah tangga. Kedua, adanya kewajiban yang dimiliki setiap orang apabila mendengar, melihat, atau mengetahui terjadinya kekerasan dalam rumah tangga untuk melakukan upaya-upaya sesuai dengan batas kemampuannya untuk mencegah berlangsungnya tindak pidana; memberikan perlindungan kepada korban; memberikan pertolongan darurat; dan membantu proses pengajuan permohonan penetapan perlindungan. Ketiga, adanya tanggungjawab kepolisian untuk memberikan perlindungan bagi setiap korban KDRT. Keempat, pelayanan apa saja yang dapat diperoleh oleh korban KDRT yang diperuntukkan sebagai upaya pemulihan akibat KDRT yang dialaminya. Kelima, adanya ancaman sanksi pidana bagi mereka yang melakukan KDRT baik yang dilakukan dengan cara kekerasan fisik, kekerasan psikis, kekerasan seksual maupun penelantaran rumah tangga.

Berbagai kententuan diatas disampaikan secara sistematis melalui kegiatan pengabdian kepada masyarakat. Materi penting yang mendapatkan penekanan adalah terkait dengan ketentuan Pasal 15 UU KDRT yang mengatur pernan masyarakat. Secara umum norma pada pasal tersebut berbunyi sebagai berikut: Setiap orang yang mendengar, melihat, atau mengetahui terjadinya kekerasan dalam rumah tangga wajib melakukan upaya-upaya sesuai dengan batas kemampuannya untuk: mencegah berlangsungnya tindak pidana; memberikan perlindungan kepada korban; memberikan pertolongan darurat; dan membantu proses pengajuan permohonan penetapan perlindungan.

Reformasi terhadap kesadaran hukum masyarakat mengenai bagaimana regulasi mengatur perihal KDRT dengan demikian menjadi kebutuhan bagi masyarakat. Kebutuhan tersebut harus dipenuhi apabila institusi hukum ingin dipastikan berhasil dalam mencapai tujuannya yaitu mencegah dan menanggulangi KDRT yang terjadi di dalam masyarakat. Dengan demikian menjadi penting agar ada upaya untuk meningkatkan kesadaran hukum Masyarakat di Kelurahan Tanjung Duren Utara, Kecamatan Grogol Petamburan Kota Administrasi Jakarta Barat.

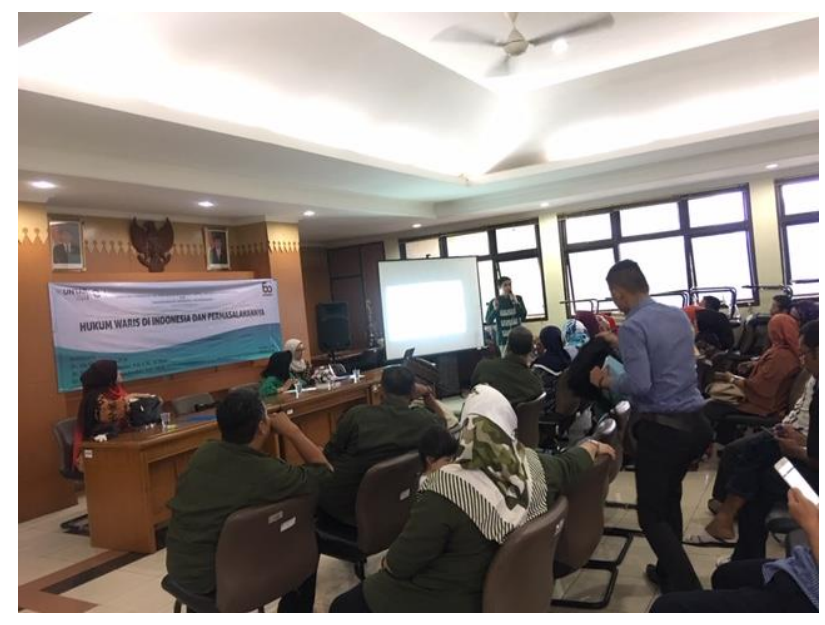

Gambar 1. Pemaparan Materi KDRT 
Pada pelaksanaan kegiatan pengabdian kepada masyarakat ini menghasilkan beberapa hal antara lain: memberikan informasi dan pemahamanan baru kepada masyarakat mengenai aturan hukum yang mengatur mengenai kekerasan dalam rumah tangga; masyarakat mendapatkan pemahaman berkenaan dengan langkah pencegahan terhadap kekerasan dalam rumah tangga; masyarakat mendapatkan pemahaman mengenai kebijakan hukum pidana yang ditetapkan oleh pemerintah dalam menanggulangi tindak pidana kekerasan dalam rumah tangga; dan masyarakat mendapatkan pemahaman mengenai peran yang harus dijalankan dalam rangka membantu melakukan pencegahan terhadap kekerasan dalam rumah tangga. Serta membantu korban kekerasan dalam rumah tangga.

\section{KESIMPULAN}

Peningkatan kesadaran hukum masyarakat penting untuk dilakukan untuk membangun kultur hukum yang berguna memastikan sistem hukum bekerja dengan baik dalam kerangka mencegah dan menanggulangi kekerasan dalam rumah tangga. Peningkatan tersebut dapat dilakukan melalui kegiatan pengabdian kepada masyarakat yang memberikan pengayaan informasi berisi tentang substansi aturan, salah satunya berkenaan dengan peran masyarakat sebagaimana diatur dalam UU KDRT.

\section{Ucapan Terimakasih}

Ucapan terimakasih kepada Direktorat Penelitian dan Pengabdian Kepada Masyarakat Universitas Tarumanagara atas pendanaan kegiatan pengabdian kepada masyarakat yang telah diberikan. Selain itu ucapan terimakasih juga diberikan kepada Camat Kecamatan Grogol Petamburan.

\section{REFERENSI}

Pouwels, B.J. (2011). Work, family, and happines: Essays on interdependencies within families, life events, and time allocation decisions. Printed by Ipskamp Drukkers B.V.

Friedman, L. M..(1969). The legal system: a social science perpsective. New York. Russel Sage Foundation.

Soekanto, S. (1982). Kesadaran Hukum Dan Kepatuhan Hukum. Jakarta: CV Rajawali.

Queensland Domestic and Family Violence Research Centre. (2018). Domestic and family violence and its relationship to child protection. Practice paper. April 2018. Department of child Safety, Youth and Women.

Soedarto. (1977). Hukum dan hukum pidana. Bandung: Alumni Bandung.

Prodjodikoro, W. (1981). Asas-Asas Hukum Pidana Di Indonesia. Jakarta-Bandung: PT. Eresco. Tresna. (1959). Asas-asas Hukum Pidana. Jakarta: PT. Tiara Mr., Limited. 